\title{
IMPAIRED SURVIVAL AND DEVELOPMENT OF THE FALSE STABLE FLY, MUSCINA STABULANS (FALLEN) (DIPTERA: MUSCIDAE) BY PYRIPROXYFEN (A JUVENILE HORMONE ANALOGUE) By
}

KHALID SH. HAMADAH

Department of Zoology and Entomology, Faculty of Science, Al-Azhar University, Cairo, Egypt (Email: khalidhamadah@gmail.com or Khalid_hamadah@azhar.edu.eg)

\section{Abstract}

The false stable fly Muscina stabulans (Diptera: Muscidae) is worldwide distributed with medical, veterinary and forensic importance. This study investigated the disruptive effects of Pyriproxyfen on survival, development, metamorphosis and morphogenesis of this fly. A series of Pyriproxyfen $(5.0,1.0,0.5,0.1 \& 0.01 \mu \mathrm{g} / \mathrm{larva})$ was topically applied onto the early last $\left(3^{\text {rd }}\right)$ instar larvae and prepupae. Regardless the time of treatment, different larval, pupal and adult mortalities were recorded. $\mathrm{LD}_{50}$ values of pyriproxyfen were calculated as $0.242 \&$ $0.444 \mu \mathrm{g} / \mathrm{stage}$, respectively. Pyriproxyfen exhibited a shortening action on larval and pupal durations, with an exception of prolongation of pupal duration after treatment of the early last instar larvae. Adult longevity was pronouncedly shortened; and pupation was suppressed regardless the time of treatment. Adult emergence was partially blocked parallel to the dose level or in no certain trend. Various percentages of larval-pupal intermediates were recorded after treatment of early last instar larvae and some pupal-adult intermediates were produced after treatment of prepupae with the higher three doses. After prepupae treatment with lower three doses of pyriproxyfen, some failed to metamorphose into pupae and remained as permanent ones. Some deformed pupae were observed only after treatment of the last instar larvae. Topical application of pyriproxyfen onto the last instar larvae or prepupae caused emergence of some deformed adults. All deformed flies died within few days without mating.

Keywords: Adult, emergence, larva, longevity, metamorphosis, morphogenesis, mortality, pupa, toxicity.

\section{Introduction}

The intensive and discriminate uses of many conventional insecticides led to several dangerous problems, such as the environmental hazards, destruction of the natural enemies, serious toxicological problems to humans, as well as the development of insect resistance toward different insecticides (Rose, 2001; Davies et al, 2007; Costa et al, 2008; Mosallanejad and Smagghe, 2009). The alternative control agents were searched to minimize the insecticide hazards. In the last few decades, new class safe compounds were developed (IGRs) insect growth regulators (Dhadialla et al, 1998; Khan and Qamar, 2012). IGRs were not directly toxic, but act selectively on the development, metamorphosis and/or reproduction of the target pests (Nicholas et al, 1999; Martins and Silva, 2004) owing to their disruptive effects on the activity of endocrine system (Wang and Liu, 2016). On the basis of the mode of action, IGRs were grouped in three categories: i- Juvenile hormone analogues (JHAs) (=Juvenoids), ii- Ecdysteroids or ecdysone agonists and iii- Chitin synthesis inhibitors (CSIs) or moult inhibitors (Dhadialla et al, 1998; Oberlander and Silhacek, 2000).

Pyriproxyfen was registered as Knack $^{\circledR}$, Sumilarv $^{\circledR}$ and Admiral ${ }^{\circledR}$; (Sumitomo Chemical Co., Japan for controlling public health pests (Yokoyama and Miller, 1991). It is a stable compound (Mohandass et al, 2006) and safe for a variety of predatory arthropods, compatible with natural enemy conservation, less toxic to ecosystem and mammals (Naranjo et al, 2003; Korrat et al, 2012) with mild toxicity to some aquatic organisms, but nontoxic to bees (Dhadialla et al, 2005). Pyriproxyfen is a potent JHA (Hatakoshi, 2012) affecting the endocrine regulation in insects resulting thereby in a strong suppression of embryogenesis, metamorphosis and adult formation in several insects 
(Ishaaya and Horowitz, 1995; Aribi et al, 2006). It suppressed oviposition, reduced eggs viability (Ghasemi et al, 2010; Ohba et $a l, 2013$ ), reduced fecundity (Singh and Kumar, 2015), and affected some biochemical processes (Nasr et al, 2010). Pyriproxyfen was successfully used to control pests of many agricultural, horticultural crops (Korrat et al, 2012) and medical insect-vectors (Sazo et al, 2008; Moadeli et al, 2014).

The false stable fly Muscina stabulans (Diptera: Muscidae) is a blood-sucker fly (Grzywacz et al, 2015). Its maggots were frequently found in household wastes and animal excreta, decaying vegetable matter and poultry houses (Queiroz and Carvalho, 1987). Laos et al. (2004) reported that $M$. stabulans often inhabits latrines and habitats created by agriculture and other human activities. The maggots caused myiasis in animals and humans (Zumpt, 1965), with forensic importance as maggots attacked exposed and diseases human body (Schroeder et al, 2003; Gaudry, 2010) as well as dead ones (Grzywacz et al, 2017). Gunn and Bird (2011) reported that larvae were accidentally seen moving of buried corpses in tombs. $M$. stabulans is a mechanical vector of diseases, its larvae can prey on immature stages of other dipterous species an as effective control agent (Duarte et al, 2013).

The present study aimed to investigate the disruptive effects of pyriproxyfen on survival, development, metamorphosis and morphogenesis of $M$. stabulans (Fallen).

\section{Materials and Methods}

A culture of susceptible strain of the false stable fly Muscina stabulans was established at the Department of Zoology and Entomology, Faculty of Science, Al-Azhar University, under controlled laboratory conditions $\left(25 \pm 2^{\circ} \mathrm{C}, 55 \pm 5 \%\right.$ R.H., photoperiod $12 \mathrm{~h} \mathrm{~L}$ $\& 12 \mathrm{~h} \mathrm{D})$ for several generations. The culture

$$
\% \text { of test mortality - } \% \text { of control mortality }
$$

$$
\text { Corrected mortality } \%=\frac{}{100-\% \text { of control mortality }} \times 100
$$

$\mathrm{LD}_{50}$ values were calculated by Microsoft office Excel, 2007 (Finny, 1971). was originated by a sample of maggots collected from cow's manure. Maggots (larvae) were fed on an artificial diet $(200 \mathrm{~g}$ wheat bran, $100 \mathrm{~g}$ powdery milk, $3 \mathrm{~g}$ yeast $\& 200 \mathrm{ml}$ water) after Busvine (1962). Feeding larvae were kept in breeding pans covered with muslin and fitted with rubber bands. After pupation, pupae were gently collected and confined in Petri-dishes into wooden cages $(45 \times 45 \times 45 \mathrm{~cm})$. Each cage was provided with wire-gauze sides except the bottom and front side which was fitted with a small circular window attached with a cloth sleeve for feeding, handling and cleaning. Emerged adults were supplied with a food as milk diet and a piece of cotton soaked in 10-15\% sugar solution.

Pyriproxyfen, a juvenile hormone analogue with a commercial name: Admiral 10\% S C, Sumitomo ${ }^{\circledR}$ and systematic one: $2-[1-\mathrm{me}-$ thyl-2-(4-phenoxyphenoxy) ethoxy] pyridine with the molecular formula: $\mathrm{C}_{20} \mathrm{H}_{19} \mathrm{NO}_{3}$, was kindly obtained from Plant Protection Research Institute, Giza. Pyriproxyfen was diluted with acetone to five dose levels: 5.0, $1.0,0.5,0.1 \& 0.01 \mu \mathrm{g} /$ larva. Fifty larvae in ten replicates (5larvae/replicate) of the early last $\left(3^{\text {rd }}\right)$ instar and same number of prepupae were topically treated, individually, with each dose using Hamilton microapplicator (NHN 737). Similar number of replicates of early last instar larvae and prepupae were only topically treated with $1 \mu$ acetone as controls. All treated and control replicates were confined in small tubes and kept under the previously mentioned laboratory conditions. They were checked daily for feeding of larvae and recording all criteria of study.

Toxicity of pyriproxyfen was determined by mortality. All mortalities of treated and control (larvae, pupae and adults) were recorded every day and corrected according to Abbott's formula (Abbott, 1925) as follows:

Developmental durations of larvae and pupae had been calculated (mean days \pm SD). 
Richard's equation (1957) was used to calculate developmental rate. Total longevity of adult females was calculated $\mathrm{M} \pm \mathrm{SD}$ days.

Metamorphosis and morphogenesis: Pupation rate was expressed in $\%$ of the developed pupae. Adult emergence was determined in \% (Jimenez-Peydro et al. (1995) as No. of completely emerged adults / No. of pupae $\times 100$. All of the possible aberrations of metamorphosis and morphogenesis were calculated in $\%$.

Statistical analysis: Data were analyzed by Student's $t$-distribution, and refined by Bessel correction (Moroney, 1956) for the test significance of difference between means.

\section{Results}

Toxic effect of pyriproxyfen: Mortalities among larvae, pupae (puparia) and adults, after one topical application of pyriproxyfen onto early last $\left(3^{\text {rd }}\right)$ instar larvae were assorted (Tab. 1). Pyriproxyfen exhibited toxic effect parallel to its dose level because the larval mortality was in a dose-dependent course. Developed pupae completely died at dose $(5.0 \mu \mathrm{g} / \mathrm{larva})$ and various percentages of mortality were in no certain trend. But, adult mortality was in a reverse relation to pyriproxyfen dose, i.e., increasing mortality $\%$ with the decreasing dose level $(4.8,3.7$, $6.9 \& 11.1 \%$ adult mortality, at $1.0,0.5,0.1$ \& $0.010 \mu \mathrm{g} / \mathrm{larva}$, respectively, vs. $6.4 \%$ mortality of control adults). $\mathrm{LD}_{50}$ was calculated as $0.242 \mu \mathrm{g} /$ larva.

After topical application of pyriproxyfen onto prepupae, mortalities of different developmental stages were arranged (Tab. 2). Larval mortality\% was recorded in no certain trend but pupal mortality\% was in a dose-dependent course. Adult mortality\% was recorded in a similar trend. $\mathrm{LD}_{\mathbf{5 0}}$ was found $0.444 \mu \mathrm{g} /$ prepupa. Early last instar larvae were more sensitive to pyriproxyfen than prepupae.

After topical application of pyriproxyfen onto early last instar larvae, data of influenced durations of larvae, pupae and adults were listed (Tab. 3). Depending on these data, larval duration was slightly shortened. In contrast, the pupal duration was significantly prolonged, especially at the doses $1.0,0.5 \&$ $0.1 \mu \mathrm{g} /$ larva $(8.1 \pm 3.11,8.1 \pm 3.11 \& 8.0 \pm 1.84$ days, respectively, vs. $6.6 \pm 1.38$ days of control pupae). Developmental rate of treated pupae was remarkably regressed at these three dose levels. Adult longevity was pronouncedly shortened, in a dose-dependent course $(10.7 \pm 1.70,8.3 \pm 0.94,5.3 \pm 0.48 \&$ $5.1 \pm 0.40$ days, at $0.01,0.1,0.5 \& 1.0 \mu \mathrm{g} /$ larva, compared to $19.2 \pm 0.20$ days of control adult females).

After topical application of pyriproxyfen onto prepupae, the development data were summarized (Tab. 4). Pupal duration was insignificantly shortened at the majority of doses except dose $0.1 \mu \mathrm{g} /$ prepupa at which pupal duration was shortened and developmental rate was conspicuously promoted. Adult longevity was significantly shortened, in a dose-dependent fashion $(13.5 \pm 1.28$, $10.0 \pm 0.80,8.3 \pm 2.88,6.8 \pm 0.12 \& 6.7 \pm 0.12$ days, at $0.01,0.1,0.5,1.0 \& 5.0 \mu \mathrm{g} /$ prepupa, respectively, vs. $19.7 \pm 1.50$ days of controls).

Topical application of pyriproxyfen onto the early last instar larvae resulted in different features of impaired metamorphosis program (Tab. 5). Pupation rate was suppressed in a dose-dependent course. Adult emergence was partially blocked in no certain trend. An interesting feature of development impairment was the production of larvalpupal intermediates in no certain trend.

Topical application of pyriproxyfen onto the prepupae showed various features of deranged development (Tab. 6). Pupation was suppressed in no certain trend. Adult emergence was increasingly blocked parallel to dose $(89.6,78.7,68.1,50.0 \& 29.8 \%$ emergence, at $0.01,0.1,0.5,1.0 \& 5.0 \mu \mathrm{g} / \mathrm{prepu}-$ pa, respectively, vs. $98.0 \%$ controls).

One of the most attractive features of impaired development was pupal-adult intermediates production after topical application of higher three doses onto prepupae. Some treated prepupae failed to metamorphose into pupae and survived for long period as permanent prepupae, after treatment with the 
lower three doses.

As to morphogenesis, pyriproxyfen exhibited a disruptive effect on pupal morphogenesis only after treating early last instar larvae with some deformed pupae, in no certain trend, after larval treatment $(2.4,14.7,18.2$, $12.0 \& 7.1 \%$ of malformed pupae, at 0.01 , $0.1,0.5,1.0 \& 5.0 \mu \mathrm{g} /$ larva, respectively, vs. $0 \%$ control deformity). All malformed pupae perished without metamorphosis into adults.

In respect of the adult morphogenesis, topical application of pyriproxyfen onto the last instar larvae resulted in the emergence of some deformed adults, in a reverse relation to the dose level $(19.4,13.8,11.1 \&$ $00.0 \%$ deformed adults, at $0.01,0.1,0.5$ and $1.0 \mu \mathrm{g} / \mathrm{larva}$, respectively, vs. $00.0 \%$ deformation among control adults). Pyriproxyfen exhibited a similar anti-morphogenic action on the successfully emerged adults after treatment of prepupae. The percentages of deformed adults were recorded in no certain trend. The morphologically deformed adults had dwarf bodies, curly wings, atrophied mouth parts and ill-developed legs. All of them died within few days without mating.

Table 1: Toxic effect $(\%)$ of pyriproxyfen on $M$. stabulans after topical treatment of the early last instar larvae.

\begin{tabular}{|c|c|c|c|c|c|c|}
\hline $\begin{array}{c}\text { Dose } \\
(\mu \mathrm{g} / \text { larva })\end{array}$ & $\begin{array}{c}\text { Larval } \\
\text { mortality }\end{array}$ & $\begin{array}{l}\text { Pupal mor- } \\
\text { tality }\end{array}$ & $\begin{array}{l}\text { Adult mor- } \\
\text { tality }\end{array}$ & $\begin{array}{l}\text { Total mor- } \\
\text { tality }\end{array}$ & $\begin{array}{c}\text { Corrected } \\
\text { mortality }\end{array}$ & $\begin{array}{c}\mathrm{LD}_{50} \\
(\mu \mathrm{g} / \text { larva })\end{array}$ \\
\hline 5.0 & 72 & 100 & --- & 100 & 100 & \multirow{6}{*}{0.242} \\
\hline 1.0 & 50 & 16 & 4.8 & 60 & 54.6 & \\
\hline 0.5 & 34 & 18.2 & 3.7 & 48 & 40.9 & \\
\hline 0.1 & 28 & 19.4 & 6.9 & 46 & 38.6 & \\
\hline 0.01 & 16 & 14.3 & 11.1 & 36 & 27.3 & \\
\hline Control & 4 & 2.1 & 6.4 & 12 & --- & \\
\hline
\end{tabular}

No adult mortality as none emerged.

Table 2: Toxic effect $(\%)$ of pyriproxyfen on M. stabulans after topical treatment of the prepupae.

\begin{tabular}{|c|c|c|c|c|c|c|}
\hline $\begin{array}{c}\text { Dose } \\
(\mu \mathrm{g} / \text { prepupa })\end{array}$ & $\begin{array}{l}\text { Prepupal } \\
\text { mortality }\end{array}$ & $\begin{array}{c}\text { Pupal } \\
\text { mortality }\end{array}$ & $\begin{array}{c}\text { Adult } \\
\text { mortality }\end{array}$ & $\begin{array}{c}\text { Total } \\
\text { mortality }\end{array}$ & $\begin{array}{c}\text { Corrected } \\
\text { mortality }\end{array}$ & $\begin{array}{l}\mathrm{LD}_{50}(\mu \mathrm{g} / \\
\text { prepupa) }\end{array}$ \\
\hline 5.0 & 6 & 70.2 & 28.6 & 80 & 78.7 & \multirow{6}{*}{0.444} \\
\hline 1.0 & 4.0 & 50.0 & 20.8 & 62 & 59.6 & \\
\hline 0.5 & 6.0 & 31.9 & 18.8 & 48 & 44.7 & \\
\hline 0.1 & 6.0 & 21.3 & 16.2 & 38 & 34.0 & \\
\hline 0.01 & 4.0 & 10.4 & 4.7 & 18 & 12.8 & \\
\hline Control & 0.0 & 2.0 & 4.1 & 6 & --- & \\
\hline
\end{tabular}

Table 3: Developmental durations of pyriproxyfen $M$. stabulans topical treated as early last instar larvae.

\begin{tabular}{|c|c|c|c|c|}
\hline Dose $(\mu \mathrm{g} / \mathrm{larva})$ & Larval duration & Pupal duration & Pupal developmental & Adult longevity \\
\hline 5.0 & $3.8 \pm 0.4 \mathrm{a}$ & --- & --- & --- \\
\hline 1.0 & $3.7 \pm 0.5 \mathrm{a}$ & $8.1 \pm 3.11 \mathrm{~b}$ & 12.32 & $05.1 \pm 0.40 \mathrm{~d}$ \\
\hline 0.5 & $3.7 \pm 0.4 \mathrm{a}$ & $8.1 \pm 3.11 \mathrm{~b}$ & 12.32 & $05.3 \pm 0.48 \mathrm{~d}$ \\
\hline 0.1 & $3.8 \pm 0.2 \mathrm{a}$ & $8.0 \pm 1.84 \mathrm{~b}$ & 12.50 & $08.3 \pm 0.94 \mathrm{~d}$ \\
\hline 0.01 & $3.8 \pm 0.2 \mathrm{a}$ & $6.6 \pm 1.24 \mathrm{a}$ & 15.52 & $10.7 \pm 1.70 \mathrm{~d}$ \\
\hline Control & $3.9 \pm 0.4$ & $6.6 \pm 1.38$ & 15.50 & $19.2 \pm 0.20$ \\
\hline
\end{tabular}

No pupal duration measured as larval-pupal stage died; morphologically normal pupae and deformed pupae. a: insignificant different $(\mathrm{P}>0.05)$, b: significant different $(\mathrm{P}<0.05)$, d: very highly significant different $(\mathrm{P}<0.001)$

Table 4: Affected developmental durations (M+SD) of $M$. stabulans after topical application onto prepupae.

\begin{tabular}{|c|c|c|c|}
\hline Dose $(\mu \mathrm{g} / \mathrm{pupa})$ & Pupal duration & Pupal developmental & Adult longevity \\
\hline 5.0 & $6.4 \pm 1.60 \mathrm{a}$ & 16.46 & $06.7 \pm 0.12 \mathrm{~d}$ \\
\hline 1.0 & $6.4 \pm 1.62 \mathrm{a}$ & 16.47 & $06.8 \pm 0.12 \mathrm{~d}$ \\
\hline 0.5 & $6.5 \pm 1.74 \mathrm{a}$ & 16.45 & $08.3 \pm 2.88 \mathrm{~d}$ \\
\hline 0.1 & $4.6 \pm 0.80 \mathrm{~b}$ & 19.67 & $10.0 \pm 0.80 \mathrm{~d}$ \\
\hline 0.01 & $6.1 \pm 1.70 \mathrm{a}$ & 16.48 & $13.5 \pm 1.28 \mathrm{~d}$ \\
\hline Control & $6.6 \pm 4.60$ & 16.40 & $19.7 \pm 1.50$ \\
\hline
\end{tabular}

a, b, d: See previous footnote (Tab. 3). 
Table 5: Metamorphic \& morphogenic effects on M. stabulans after pyriproxyfen topical treatment of early last instar larvae.

\begin{tabular}{|c|c|c|c|c|c|}
\hline $\begin{array}{c}\text { Dose } \\
(\mu \mathrm{g} / \mathrm{larva})\end{array}$ & $\begin{array}{c}\text { Larval-pupal inter- } \\
\text { mediates }(\%)\end{array}$ & \multicolumn{2}{|c|}{ Pupal stage } & \multicolumn{2}{c|}{ Adult stage } \\
\cline { 3 - 6 } & 04.0 & 28 & 07.1 & --- & Pupation (\%) \\
\hline 5.0 & 06.0 & 50 & 12.0 & 84.0 & --- \\
\hline 1.0 & 08.0 & 66 & 18.2 & 81.8 & 11.1 \\
\hline 0.5 & 12.0 & 72 & 14.7 & 80.1 & 13.8 \\
\hline 0.1 & 10.0 & 84 & 02.4 & 85.7 & 19.4 \\
\hline 0.01 & 00.00 & 96 & 00.0 & 97.9 & 00.0 \\
\hline Control & & &
\end{tabular}

*Deformed pupae perished without metamorphosis into adults. **Deformed adults with curly wings, atrophied mouth parts and ill-developed legs. Adult females perished within few days without mating.

Table 6: Metamorphic \& morphogenic effects of pyriproxyfen on M. stabulans prepupae after topical treatment.

\begin{tabular}{|c|c|c|c|c|c|c|}
\hline \multirow{2}{*}{$\begin{array}{c}\text { Dose } \\
(\mu \mathrm{g} / \text { prepupa) }\end{array}$} & Permanent & \multirow{2}{*}{$\begin{array}{c}\text { Pupal-adult in- } \\
\text { prepupae }\end{array}$} & \multicolumn{2}{|c|}{ Pupal stage } & \multicolumn{2}{c|}{ Adult stage } \\
\cline { 4 - 6 } & termediates & Pupation & Deformities* & Emergence & deformities** \\
\hline 5.0 & $0.0 \%$ & $2.1 \%$ & $94 \%$ & $0.0 \%$ & $29.8 \%$ & $28.6 \%$ \\
\hline 1.0 & $0.0 \%$ & $4.2 \%$ & $96 \%$ & $0.0 \%$ & $50.0 \%$ & $20.8 \%$ \\
\hline 0.5 & $6.0 \%$ & $2.9 \%$ & $94 \%$ & $0.0 \%$ & $68.1 \%$ & $06.3 \%$ \\
\hline 0.1 & $6.0 \%$ & $0.0 \%$ & $94 \%$ & $0.0 \%$ & $78.7 \%$ & $24.3 \%$ \\
\hline 0.01 & $4.1 \%$ & $0.0 \%$ & $96 \%$ & $0.0 \%$ & $89.6 \%$ & $27.9 \%$ \\
\hline
\end{tabular}

\section{Discussion}

Several insect growth regulators (IGRs) had been reported to exhibit toxic effects on different insect species. However, toxic effects of pyriproxyfen on some insect species had been reported, such as the Sunn pest Eurygaster integriceps (Mojaver and Bandani, 2010), the migratory locust Locusta migratoria (Hu et al, 2012), the tobacco cutworm Spodoptera litura (Kaur and Chandi, 2015) and the lawn armyworm Spodoptera mauritia (Resmitha and Meethal, 2016), the southern house mosquito $C x$. quinquefasciatus (Khan et al, 2016) and the pink boll worm Pectinophora gossypiella (Sabry and Abdou, 2016). The present results, to some extent, agreed with the previously reported results, since topical application of pyriproxyfen onto early last $\left(3^{\text {rd }}\right)$ instar larvae resulted in larval mortality in a dose-de-pendent course. All pupae died at the highest dose and various pupal mortalities were caused by other doses. Adult mortality was observed in a reverse relation to the dose level. After topical application onto prepupae, larval mortality was recorded in no certain trend but pupal and adult mortalities were observed in the dose-dependent course. However, the present larval mortality might be attributed to the moulting pre- vention to gain air for splitting the old cuticle and expand the new one (Linton et al., 1997). Larval mortality might be due to feed lack and starvation (Ghoneim et al, 2000). Pupal mortality could be related to hormonal activity of pyriproxyfen or other causes, as suffocation, bleeding, desiccation, or failure of vital homeostatic mechanisms (Smagghe and Degheele, 1994). Adult mortality might be due to retention and distribution of pyriproxyfen in insect body by direct and rapid transport via haemolymph to other tissues, and/or by lower detoxification capacity of the adults (Osman et al, 1984). In the current study, pyriproxyfen $\mathrm{LD}_{50}$ was calculated as $0.242 \& 0.444 \mu \mathrm{g} / \mathrm{insect}$ after larvae \& prepupae treatment, respectively. This finding agreed with many studies reporting that the early larval instars of flies were more susceptible than later ones to some IGRs, such as Musca domestica (Fouda et al., 1991), Lucilia cuprina (Friedel and Mc-Donell, 1985), Fannia spp. (Meyer et al, 1987) and Ceratitis capitata (Vinuela et al, 1993).

In the present study, pyriproxyfen exhibited a major shortening action on larval and pupal durations, regardless time of treatment. These results were concomitant to short larval duration of some insects after IGRs treatment, as the desert locust Schis- 
tocerca gregaria treated with lufenuron (Ba$\mathrm{kr}$ et al, 2008), P. gossypiella treated with methoxyfenozide (Sabry and Abdou, 2016) and $P$. unionalis treated with novaluron (Ghoneim et al, 2017b). The present shortened larval and pupal durations might be due to their avoiding pyriproxyfen adverse action, as a xenobiotic agent. Pyriproxyfen might prevent nuclear receptors formation of the cells, caused disturbance in developmental durations (Riddiford and Truman, 1993).

In the present study, Adult longevity was pronouncedly shortened, in a dose-dependent course, regardless the time of treatment with pyriproxyfen. This result agreed with the shortening action of various IGRs, such as $S$. littoralis by Novaluron (Hamadah et al, 2015); the Oriental fruit moth Grapholita molesta (Reinke and Barrett, 2007) and the beet armyworm Spodoptera exigua (Luna et al, 2011) by methoxyfenozide; G. pyloalis by lufenuron (Aliabadi et al, 2016); P. gossypiella by chlorfluazuron (Kandil et al, 2005; Salem, 2015). The shortened adult longevity might be attributed to interference of pyriproxyfen with the hormonal regulation of adult longevity because a close relation between certain hormones and adult longevity was reported in other insects, such as the vinegar fly Drosophila melanogaster melanogaster (Broughton et al, 2005; Carbone et al, 2006; Chamseddin et al, 2012).

The insect fat body serves many vital functions (Arrese and Soulages, 2010) and thus, the longevity mechanisms occurred within this tissue (Hwangbo et al, 2004). Pyriproxyfen might adversely affect the fat bodies resulting in shortened adult longevity.

In the present study, pupation was drastically inhibited, in a dose-dependent course or in no certain trend, depended on pyriproxyfen treatment. This result was more or less consistent with the report of regressed pupation rate of some insects by the suppressive action of various IGRs, such as the grey flesh fly Parasarcophaga argyrostoma by pyriproxyfen (Ismail, 1995) and chlorofluazuron (Ghoneim and Ismail, 1995); the diamondback moth Plutella xylostella by hexaflumuron (Mahmoudvand et al, 2012); S. littoralis by novaluron (Ghoneim et al, 2015); G. pyloalis by lufenuron (Aliabadi et $a l, 2016)$ and fenoxycarb (Singh and Tiwari, 2016); the whitefly parasitic wasp Encarsia formosa by pyriproxyfen and fenoxycarb (Wang and Liu, 2016); P. gossypiella (Ghoneim et al, 2017a) and P. unionalis (Ghoneim et al, 2017c) by novaluron. The inhibited pupation might be due to an inhibitory effect of this compound on the synthesis of specific storage proteins by fat body on last larval instar and their deposition at pupation time (Gupta, 1985).

In the present study, adult eclosion was hindered after topical application of methoprene onto larvae of Aedes aegypti (Braga et al, 2005), Cx. cephalonica (Tripathi and Tiwari, 2006), Cx. quinquefasciatus and Ae. albopictus (Khan et al, 2016; Bibbs et al, 2017). Pyriproxyfen treatment resulted in the inhibition of adult emergence of $P$. argyrostoma (Ismail, 1995), CX. quinquefasciatus and Aedes albopictus (Khan et al, 2016), D. melanogaster (Benseba et al, 2015) and E. formosa (Wang and Liu, 2016). These results more or less agreed with the previously reports, since pyriproxyfen topical application onto last instar larvae or prepupae partially blocked adult emergence. Thus, it was important to emphasize that the adult emergence in insects is a crucial physiological process and regulated by the eclosion hormone. Disturbance of this hormone partially or completely arrested the adults to emerge (Josephrajkumar et al, 1999). On the molecular basis, the $\mathrm{JH}$ mimics compounds might cause miss-expression of certain genes, particularly the brood complex $(b r-\mathrm{C})$ transcription factor gene, leading to symptoms of impaired metamorphosis, like blocking of adult emergence (Wilson, 2004; Nandi and Chakravarty, 2011).

In the current study, pyriproxyfen topical application onto early last instar larvae produced various percentages of larval-pupal intermediates, in no certain trend, but some 
pupal-adults were produced after topical application of higher three doses onto the prepupae. These mosaic creatures perished soon after production. This agreed with some of the reported larval-pupal intermediates after IGRs treatment. Some larval-pupal intermediates were formed after treatment of $3^{\text {rd }}$ instar larvae of $P$. argyrostoma with $150 \mu \mathrm{g} /$ larva of chlorfluazuron (Ghoneim and Ismail, 1995). Also, treatment with some juvenoids induced the production of larval-pupal intermediates or larviform pupae in the stable fly Stomoxys calcitrans and the flesh fly Sarcophaga bullata (Wright, 1970; Weaver and Begley, 1982). In the present study, production of intermediate creatures indicated the metamorphosis disturbance by pyriproxyfen. This juvenoid interfered with the hormonal regulation of pupation program (Al-Sharook et al, 1991). But, pyriproxyfen might inhibit metamorphosis program via an ecdysteroid reduction and/or interference with the release of neurosecretion (Josephrajkumar et al, 1999) that indicated a juvenile property of pyriproxyfen disrupting the perfect larval-pupal transformation or production of these mosaic creatures resulted by pyriproxyfen inhibitory effect on DNA synthesis (Mitlin et al, 1977) or the chitin biosynthesis and chitin synthase (Mayer et al, 1980). The induction had lethal consequences as a rapid moult did not have enough time for the completion transformation. Thus, the insects moulted to nonviable forms between the stages (Tateishi et al, 1993). Molts induced during the early phase of the last instar produce larval-like individuals, while those formed in the late phase generate pupal-like individuals (Eizaguirre et al, 2007). In insects, one symptom of the suspended metamorphosis has attracts a great attention of some entomologists. This feature is usually expressed in 'permanent larvae'. The induction of permanent larvae or nymphs was recorded in some insect species as a response to some IGRs. Permanent larvae of the European corn borer Ostrinia nubilalis were induced depending upon the dose of fenoxycarb and the timing of application onto the $5^{\text {th }}$ instar larvae (Gadenne et $a l, 1990)$. Permanent larvae of the grey flesh fly Parasarcophaga argyrostoma were induced after chlorfluazuron treatment with $100 \mu \mathrm{g} /$ larva (Ghoneim and Ismail, 1995). Feeding of the greater wax moth Galleria mellonella larvae, for a long time, on a diet treated with the $\mathrm{JH}$ analogue $(0.1 \mathrm{mg} / \mathrm{g}$ of diet) induced permanent larvae (Slama and Lukas, 2013). Results of the present investigation on $M$. stabulans were in agreement with the previously reported results, since treatment of prepupae with the lower three doses of pyriproxyfen suppressed some prepupae to metamorphose into pupae but survived for long period as permanent prepupae. To understand appearance of the permanent prepupae in the present study, pyriproxyfen might disrupt the ecdysteroid metabolism or might alternatively act directly to inhibit the release of ecdysis-triggering hormone (Gaur and Kumar, 2010; Gibbens et al, 2011).

In the present study, pyriproxyfen exerted an impaired pupal morphogenesis only after early last instar larvae treatment, some deformed pupae were observed. These agreed with the report of impaired pupal morphogenesis in $S$. frugiperda after feeding of $5^{\text {th }}$ instar larvae on methoxyfenozide treated diet (Zarate et al, 2011), C. cephalonica after fenoxycarb topical application on last instar larvae (Begum and Qamar, 2016), P. gossypiella after novaluron treatment of the full grown larvae (Ghoneim et al, 2017a) and $P$. unionalis after novaluron treatment of newly moulted last instar larvae (Ghone-im et $a l, 2017 \mathrm{c}$ ). Anti-morphogenic activity of pyriproxyfen against pupae might exert suppressive action on the chitin synthesis and prevented normal deposition of new cuticle during apolysis led to pupal deformities (Retnakaran et al, 1985). Pyriproxyfen might block the release of morphogenic peptides and alternated titers of ecdysteroids and juvenoids (Barnby and Klocke, 1990).

Disrupted adult morphogenesis occurred 
after IGRs treatment as $S$. littoralis treated with novaluron (Hamadah et al, 2015); E. integriceps treated with pyriproxyfen (Mojaver and Bandani, 2010); S. frugiperda treated with methoxyfenozide (Zarate et al, 2011); E. kuehniella treated with hexaflumuron (Ashouri et al, 2014); H. armigera treated with hexaflumuron (Taleh et al, 2015); $C$. cephalonica treated with fenoxycarb (Begum and Qamar, 2016). Pyriproxyfen exerted ecdysteroid titer disturbance in lysosomal enzyme activity causing abnormal adult (Josephrajkumar et al, 1999), or chitin synthase was inhibited by the compound metabolites (Cohen and Casida, 1980), inhibited DNA synthesis or facilitated diffusion and active transport across nucleosides and amino acids cell membranes (Mayer et al, 1988).

\section{Conclusion}

Pyriproxyfen exhibited toxic effects on larvae, pupae and adults as some disruptive effects on development and metamorphosis as well as anti-morphogenic action on pupae and adults. Pyriproxyfen proved an effective agent in controlling this fly.

\section{Acknowledgement}

The author thanks Dr. Heba Hassan, Professor at Plant Protection Research Institute, Giza, for kindly providing the pyriproxyfen used in this study.

\section{References}

Abbott, WS, 1925: A method of computing the effectiveness of insecticide. J. Econ. Entomol. 18, 2:265-7.

Aliabadi, FP, Sahragard, A, Ghadamyari, M 2016: Lethal and sublethal effects of a chitin synthesis inhibitor, lufenuron, against Glyphodes pyloalis Walker (Lepidoptera: Pyralidae). J. Crop Prot. 5, 2:203-14.

Al-Sharook, Z, Balan, K, Jiang, Y, Rembold, H, 1991: Insect growth inhibitors from two tropical Meliaceae: Effects of crude seed extracts on mosquito larvae. J. App. Entomol. 111:425-30.

Aribi, N, Smagghe, G, Lakbar, C, Soltani-Ma zouni, N, Soltani, N, 2006: Effect of pyriproxyfen a juvenile hormone analogue, on development of the mealworm, Tenebrio molitor. Pestic. Biochem. Phys. 84:55-62.

Arrese, EL, Soulages, JL, 2010: Insect fat body: Energy, metabolism and regulation. Ann.
Rev. Entomol. 55:207-25.

Ashouri, S, Pourabad, RF, Ebadollahi, A, 2014: The effect of diflubenzuron and hexaflumuron on the last larval instars of the Mediterranean flour moth Anagasta kuehniella (Zeller) (Lepidoptera: Pyralidae) under laboratory conditions. Arch. Phytopathol. Plant Protect. 47, 1:7581.

Bakr, RFA, Hussein, MA, Hamouda, LS, Hassan, HA, Elsokary, ZF, 2008: Effect of some insecticidal agents on some biological aspects and protein patterns of desert locust, Schistocerca gregaria (Forskal). Egypt. Acad. Soc. Environ. Develop. 9, 2:29-42.

Barnby, MA, Klocke, JA, 1990: Effects of azadirachtin on levels of ecdysteroids and prothoracic-otropic hormone-like activity in Heliothis virescens (Fabr.) larvae. J. Insect Physiol. 36: 125-31.

Begum, R, Qamar, A, 2016: Fenoxycarb- a potent inhibitor of metamorphosis and reproduction in rice moth, Corcyra cephalonica (Stainton). J. Entomol. Zool. Studies 4, 4:572-7.

Benseba, F, Kilani-Morakchi, S, Aribi, N, Solatani, N, 2015: Evaluation of pyriproxyfen, a juvenile hormone analog, on Drosophila melanogaster (Diptera: Drosophilidae): insecticidal activity, ecdysteroid contents and cuticle formation. Eur. J. Entomol. 112, 4: 625-31.

Bibbs, CS, Anderson, CS, Smith, ML, Xue, R D, 2017: Direct and indirect efficacy of truckmounted applications of s-methoprene against Aedes albopictus (Diptera: Culicidae). Int. J. Pest Manag. 63:1-8.

Braga, IA, Mello, CB, Peixoto, AA, Valle, D, 2005: Evaluation of methoprene effect on Aedes aegypti (Diptera: Culicidae) development in laboratory conditions. Mem. Inst. Oswaldo Cruz, Rio de Janeiro 100, 4:435-40.

Broughton, SJ, Piper, MD, Ikeya, T, Bass, T M, Jacobson, J, et al, 2005: Longer lifespan, altered metabolism, and stress resistance in Drosophila from ablation of cells making insulin-like ligands. Proc. Natl. Acad. Sci. U.S.A. 102: 3105-10.

Busvine, JR, 1962: A laboratory technique for measuring the susceptibility of house flies and blow flies to insecticides. Lab. Pract. 11:464-8.

Carbone, MA, Jordan, KW, Lyman, RF, Harbison, ST, Leips, J, et al, 2006: Phenotypic variation and natural selection at catsup, a pleiotropic quantitative trait gene in Drosophila. Curr. Biol. 16:912-9. 
Chamseddin, KH, Khan, S, Nguyen, MLH, Bauer, J, 2012: Takeout-dependent longevity is associated with altered juvenile hormone signaling. Mech. Ageing develop.133:11-2.

Cohen, E, Casida, JE, 1980: Inhibition of Tribolium gut synthetase. Pestic. Biochem. Physiol. 13:129-31.

Costa, LG, Giordano, G, Guizzetti, M, Vitalone, A, 2008: Neurotoxicity of pesticides: A brief review. Frontiers BioSci. 13:1240-9.

Davies, TGE, Field, LM, Usherwood, PNR, Williamson, MS, 2007: DDT, pyrethrins and insect sodium channels. IUBMB Life 59:151-62.

Dhadialla, TS, Carlson, G, Le, DP, 1998: New insecticides with ecdysteroial and juvenile hormone activity. Ann. Rev. Entomol. 43:545-69.

Dhadialla, TS, Retnakaran, A, Smagghe, G, 2005: Insect growth and development disrupting insecticides. In: Comprehensive Insect Molecular Science (Gilbert, L.I, Kostas, I. and Gill, S, eds.). Vol. 6. Pergamon Press, New York, NY.

Duarte, JLP, Krüger, RF, Ribeiro, PB 2013: Interaction between Musca domestica L. and its predator Muscina stabulans (Fallén) (Diptera, Muscidae): Effects of prey density and food source abundance. Rev. Brasil. Entomol. 57:55-8.

Eizaguirre, M, López, C, Schafellner, Ch, Sehnal, F, 2007: Effects of ecdysteroid agonist RH-2485 reveal interactions between ecdysteroids and juvenile hormones in the development of Sesamia nonagrioides. Arch. Insect Biochem. Physiol. 65:74-84.

Finney, DJ, 1971: Probit analysis. $3^{\text {rd }}$ ed. Cambridge, England: Cambridge University Press.

Fouda, MA, Ghoneim, KS, Bream, AS, 1991: Biological activity of fenoxycarb (Ro 13-5223) against housefly, Musca domestica. J. Egypt. Ger. Soc. Zool. 5:277-88.

Friedel, T, McDonell, PA 1985: Cyromazine inhibits reproduction and larval development of the Australian sheep blow fly (Diptera: Calliphoridae). J. Econ. Entomol. 78: 868-73.

Gadenne, C, Grenier, S, Mauchamp, B, Plantevin, G 1990: Effects of a juvenile hormone mimetic, fenoxycarb, on postembryonic development of the European corn borer, Ostrinia nubilalis Hbn. Exp. 46:744-7.

Gaudry, E 2010: The insect colonization of buried remains. In: Current Concepts in Forensic Entomology (Amendt, J, Goff, M, Campobasso, $\mathrm{CP}$, Grassberger, M, eds), Springer, Dordrecht.

Ghasemi, A, Sendi, JJ, Ghadamyari, M, 2010: Physiological and biochemical effect of Pyri- proxyfen on Indian meal moth Plodia interpunctella (Hubner) (Lepidoptera: Pyralidae). J. Plant Protect. Res. 50, 4: 416-22.

Ghoneim, KS, Ismail, IE, 1995: Survival, developmental and morphogenic deficiencies of Parasarcophaga argyrostoma (Diptera: Sarcophagidae) induced by the chitin biosynthesis inhibitor, Chlorefluazuron (IKI-7899). J. Egypt. Soc. Parasitol. 25, 2:561-81.

Ghoneim, KS, Mohamed, HA, Bream, AS, 2000: Efficacy of the Neem seed extract, Neemazal, on growth and development of the Egyptian cotton leafworrn, Spodoptera littoralis Boisd. (Lepidoptera: Noctuidae). J. Egypt. Ger. Soc. Zool. 33:161-79.

Ghoneim, K, Hamadah Kh, El-Hela, A; Mohammad, A, Amer, M, 2015: Efficacy of Nigella sativa (Ranunculaceae) Extracts on Adult Performance and Phase Transition of the Desert Locust Schistocerca gregaria (Orthoptera: Acrididae). Int. J. Res. Stud. Zool. 1, 2:29-44.

Ghoneim, K, Hassan, HA, Tanani, MA, Bakr, NA 2017a: Toxic and disruptive effects of Novaluron, a chitin synthesis inhibitor, on development of the pink bollworm Pectinophora gossypiella (Saunders) (Lepidoptera: Gelechiidae). Int. J. Entomol. Res. 2, 2:36-47.

Ghoneim, K, Hassan, HA, Tanani, MA, Bakr, NA 2017b: Deteriorated larval haemogram in the pink bollworm Pectinophora gossypiella (Saunders) (Lepidoptera: Gelechiidae) by the chitin synthesis inhibitors, Novaluron and Diofenolan. Int. J. Mod. Res. Rev. 5, 2:1487-504.

Ghoneim, K, Hamadah, Kh, Mansour, AN, Abo-Elsoud, AA, 2017c: Toxicity and disruptive impacts of Novaluron, a chitin synthesis inhibitor, on development and metamorphosis of the olive leaf moth Palpita unionalis (Hübner) (Lepidoptera: Pyralidae). Int. J. Trend Res. Develop. 4, 3:184-93.

Gibbens, YY, Warren, JT, Gilbert, LI, O' Connor, MB, 2011: Neuroendocrine regulation of Drosophila metamorphosis requires TGFb/ Activin signaling. Develop. 138:2693-703.

Grzywacz, A, Hall, MJ, Pape, T, 2015: Morphology successfully separates third instar larvae of Muscina. Med. Vet. Entomol. 29, 3:31429.

Grzywacz, A, Hall, MJR, Pape, T, Szpila, K, 2017: Muscidae (Diptera) of forensic importannce of an identification key to third instar larvae of the western Palaearctic Region and a catalogue of the muscid carrion community. Int. J. 
Legal Med. 131, 3:855-66.

Gunn, A, Bird, J, 2011: The ability of blowflies Calliphora vomitoria (Linnaeus), Calliphora vicina (Rob-Desvoidy) and Lucilia sericata (Meigen) (Diptera: Calliphoridae) and the muscid flies Muscina stabulans (Fallén) and Muscina prolapsa (Harris) (Diptera: Muscidae) to colonise buried remains. Forensic Sci. Int. 207:198204.

Gupta, AP, 1985: Cellular elements in the haemolymph. In: Comprehensive Insect Physiology, Biochemistry and Pharmachology (Kerkt, GA, Gilbert, LI, eds.). Pergamon Press, Oxford.

Hamadah, Kh, Tanani, M, Ghoneim, K, Basiouny, A, Waheeb, H, 2015: Effectiveness of Novaluron, chitin synthesis inhibitor, on the adult performance of Egyptian cotton leafworm, Spodoptera littoralis (Boisd.) (Lepidoptera: Noctuidae). Int. J. Res. Stud. Zool. 1, 2:45-55.

Hamadah, Kh, Ghoneim, K, Mansour, AN, Abo Elsoud, AA, 2017: Deranged adult performance and reproductive potential of the olive leaf moth Palpita unionalis (Hübner) (Lepidoptera: Pyralidae) by the non-steroidal ecdysone agonist, Methoxyfenozide. Int. J. Inform. Res. Rev. 4, 6:4228-40.

Hassan, HA, Ghoneim, K, Tanani, MA, Bakr, NA 2017: Impairing effectiveness of the chitin synthesis inhibitor, Novaluron, on adult performance and reproductive potential of the pink bollworm Pectinophora gossypiella (Saunders) (Lepidoptera: Gelechiidae). J. Entomol. Zool. Stud. 5, 2:581-92.

Hatakoshi, M, 2012: Pyriproxyfen: a new juvenoid. In: Modern Crop Compound (Kramer W, Schirmer, U, Jeschke, P, Witschel, M, eds). $2^{\text {nd }}$ ed., Wiley-VCH, Weinheim.

Hu, BZ, Xu, Y, Zheng, XR, Shi, WP, 2012: Molt disruption and mortality of Locusta migratoria var. manilensis (Meyen) (Orthoptera: Acrididae) caused by insect growth regulators. Afri. J. Biotechnol. 11, 16:3882-7.

Hwangbo, DS, Gersham, B, Tu, MP, Palmer, M, Tatar, M 2004: Drosophila dFOXO controls lifespan and regulates insulin signaling in in the brain and fat body. Nature 429:562-56.

Ishaaya, I, Horowitz, AR, 1995: Pyriproxyfen, a novel insect growth regulator for controlling whiteflies: Mechanism and resistance management. Pest. Sci. 43:227-32.

Ismail, IE, 1995: Effectiveness of the JHA, pyriproxyfen (S-31183), on the development and morphogenesis of the grey flesh fly Parasarco- phaga argyrostoma (Diptera: Sarcophagidae). Egypt. J. App. Sci. 10:223-32.

Jimenez-Peydro, R, Gimeno-Martos, C, Lopez-Ferror, J, Serrano- Delgado, C, MorenoMari, J, 1995: Effects of the insect growth regulator, cyromazine, on the fecundity, fertility and offspring development of Mediterranean fruit fly, Ceratitis capitata Wied (Diptera, Tephritidae). J. App. Entomol. 119:435-8.

Josephrajkumar, A, Subrahmanyam, B, Srinivasan, S, 1999: Plumbagin and azadirachtin deplete haemolymph ecdysteroid levels and alter the activity profiles of two lysosomal enzymes in the fat body of Helicoverpa armigera (Lepidoptera: Noctuidae). Euro J. Entomol. 96:347-53.

Kandil, AAM, Abd El-Zhar, TR, Rashad, A M, 2005: Some biological and biochemical effects of chitin synthesis inhibitor on pink bollworm Pectinophora gossypiella. Ann. Agric. Sci. Moshtohor 43, 4:1991-2002.

Kaur, K, Chandi, AK, 2015: Toxicity of Pyriproxyfen against Tobacco caterpillar, Spodoptera litura (Fabricius). Int. J. Sci. Res. 4, 11:481-3. Khan, I, Qamar, A, 2012: Andalin, an insect growth regulator, as reproductive inhibitor for red cotton stainer, Dysdercus koenigii (F.) (Hemiptera: Pyrrhocoridae). Acad. J. Entomol. 5, 2: 113-21.

Khan, I, Qureshi, N, Khan, SA, Ali, A, Ahmad, M, et al, 2016: Efficacy of several plant extracts as growth inhibitors against red flour beetle, Tribolium castaneum (Herbst) (Coleoptera: Tenebrionidae). Acta Zool. Bulga. 68, 3:443-50.

Korrat, EEE, Abdelmonem, AE, Helalia, AA R, Khalifa, HMS, 2012: Toxicological study of some conventional and nonconventional insecticides and their mixtures against cotton leaf wo$\mathrm{rm}$, Spodoptera littoralis (Boisd.) (Lepidoptera: Noctuidae). Ann. Agric. Sci. 57, 2:145-52.

Laos, F, Semenas, LG, Labud, VA 2004: Factors related to the attraction of flies at a biosolids compositing facility (Bariloche, Argentina). Sci. Total. Environ. 328:33-40.

Linton, YM, Nisbet, AJ, Mordue (Luntz), AJ, 1997: The effect of azadirachtin on the testes of the desert locust Schistocerca gregaria (Forskal). J. Insect Physiol. 43:1077-84.

Luna, JC, Robinson, VA, Martinez, AM, Schneider, MI, Figueroa, JI, et al, 2011: Long-te$\mathrm{rm}$ effects of methoxyfenozide on the adult reproductive processes and longevity of Spodoptera exigua (Lepidoptera: Noctuidae). J. Econ.

Entomol. 104, 4:1229-35. 
Mahmoudvand, M, Abbasipour, H, SheikhGarjan, A, Bandani, AR, 2012: Decrease in pupation and adult emergence of Plutella xylostella (L.) treated with hexaflumuron. Chilean J. Agric. Res. 72, 2:206-11.

Martins, F, Silva, I, 2004: Avaliação da atividade inibidora do diflubenzuron na ecdise das larvas de Aedes aegypti (Lin, 1762) (Diptera, Culicidae). Rev. Soc. Bras. Med. Trop. 37: 135-8.

Mayer, RT, Chen, AC, DeLoach, JR, 1980: Characterization of a chitin synthase from the stable fly, Stomoxys calcitrans L. Insect Biochem. 10:549-56.

Meyer, JA, McKeen, WD, Mullen, BA, 1987: Factors affecting control of Fannia spp. (Diptera: Muscidae) with cyromazine feed-through on caged-layer facilities in Southern California. J. Econ. Entomol. 80:817-21.

Mitlin, N, Wiygul, G, Haynes, JW, 1977: Inhibition of DNA synthesis in boll weevil (Anthonomus grandis Boheman) sterilized by dimilin. Pesti. Biochem. Physiol. 7:559-63.

Moadeli, T, Hejazi MJ, Golmohammadi, G 2014: Lethal effects of pyriproxyfen, spinosad, and indoxacarb and sublethal effects of pyriproxyfen on the $1^{\text {st }}$ instar larvae of beet armyworm, Spodoptera exigua Hübner (Lepidoptera: Noctuidae) in the laboratory. J. Agric. Sci. Tech. 16:178-89.

Mohandass, S, Arthur, F, Zhu, K, Throne, J, 2006: Hydroprene: mode of action current status in stored-product pest management, insect resistance \& future prospects. Crop Protect. 9:902-9.

Mojaver, M, Bandani, AR, 2010: Effects of the insect growth regulator pyriproxyfen on immature stages of sunn pest, Eurygaster integriceps Puton (Heteroptera: Scutelleridae). Munis Entomol. Zool. 5, 1:187-97.

Moroney, MJ, 1956: Facts from Figures. $3^{\text {rd }}$ ed. Penguin Books Ltd.; Harmondsworth, Middlesex.

Mosallanejad, H, Smagghe, G, 2009: Biochemical mechanisms of methoxyfenozide resistance in the cotton leafworm Spodoptera littoralis.

Pest Manage. Sci. 65:732-6.

Nandi, PS, Chakravarty, K, 2011: Juvenoids and anti-Juvenoids as third generation pesticide to control lepidopteran field crop pests. Indian Streams Res. J. 1, 6:15-9

Naranjo, SE, Hagler, JR, Ellsworth, P, 2003: Improved conservation of natural enemies with selective management systems for Bemisia tabaci in cotton. Biocontrol Sci. Tech. 13:571-87.
Nasr, HM, Badawy, M, Rabea, EI, 2010: Toxicity and biochemical study of two insect growth regulators, buprofezin and pyriproxyfen, on cotton leafworm Spodoptera littoralis. Pesti. Biochem. Physiol. 98, 2:198-205.

Nicholas, AH, Thwaite, WG, Spooner-Hart, R N, 1999: Arthropod abundance in a disruption and supplementary insecticide treatments for codling moth, Cydia pomonella (L) (Lepidoptera: Torticidae). Aust. J. Entomol. 38:23-29.

Oberlander, H, Silhacek, D, 2000: Insect growth regulators, In: Alternatives to Pesticides in Stored-Product IPM (Subramanyam, B, Hagstruum, DW); Kluwer Academic Publishers, Boston. Ohba, S, Ohashi, K, Pujiyati, E, Higa, Y, Kaw ada, H, et al, 2013: The effect of pyriproxyfen as a population growth regulator against Aedes albopictus under semi-field conditions. PLoS One, 8, 7:e67045

Osman, EE, Rarwash, I, El- Samadisi, MM, 1984: Effect of the anti-moulting agent "Dimilin" on the blood picture and cuticle formation in Spodopterea littoralis (Boisd.) larvae. Bull. Entomol. Soc. Egypt. (Econ.) 14:3-46.

Queiroz de, SMP, Carvalho de, CJB, 1987: Chave pictórica e descrições de larvas de $3^{\circ}$ ínstar de Diptera (Calliphoridae, Muscidae e Fanniidae) em vazadouros de resíduos sõlidos domésticos em Curitiba, Paraná. Ana. Soc. Entomol. Brasil. 16:265-88.

Reinke, MD, Barrett, BA, 2007: Fecundity, fertility and longevity reductions in adult oriental fruit moth (Lepidoptera: Tortricidae) exposed to surfaces treated with the ecdysteroid agonists tebufenozide and methoxyfenozide. J. Entomol. Sci. 42:457-66.

Resmitha, C, Meethal, KV, 2016: Toxicity of insect growth regulator, pyriproxyfen, on larvae of Spodoptera mauritia Boisd (Lepidoptera: Noctuidae). Int. J. Agric. Innova. Res. 5, 1:173-6.

Retnakaran, A, Granett, J, Ennis, T, 1985: Insect growth regulators. In: Comprehensive Insect Physiology, Biochemistry \& Pharmacology (Kerkut, GA, Gilbert, LI, eds.). Vol. 12; Pergamon, Oxford.

Richard, AG, 1957: Cumulative effects of optimum and suboptimum temperatures on insect development. In: Influence of Temperature on Biological Systems (Johnson, FH, ed.). Ronald Press Co., New York.

Riddiford, LM, Truman, JW, 1993: Hormone receptors and the regulation of insect metamorphosis. Am. Zool. 33:340-7. 
Rose, RI, 2001: Pesticides and public health: integrated methods of mosquito management. Emerg. Infect. Dis. 7, 1:17-23.

Sabry, KH, Abdou, GY, 2016: Biochemical and toxic characterization of some insect growth regulators to the pink bollworm, Pectinophora gossypiella (Saunders). Am-Eurasian J. Sustain. Agric. 10, 1:8-14.

Salem, MSM, 2015: Latent effect of different compounds on Pectinophora gossypiella (Saunders). J. Plant Prot. Path., Mansoura Univ. Egypt 6, 2:269-79.

Sazo, L, Araya, JE, Esparza, S, 2008: Control of San Jose scale nymphs, Diaspidiotus perniciosus (Comstock), on almond and apple orchards with pyriproxyfen, phenoxycarb, chlorpyrifos, and mineral oil. Chilean J. Agric. Res. 68:284-9.

Schroeder, H, Klotzbach, H, Püschel, K 2003: Insects' colonization of human corpses in warm and cold season. Forensic Sci. Int. 5:372-4.

Singh, S, Kumar, K 2015: Effects of juvenoid pyriproxyfen on reproduction and F1 progeny in myiasis causing flesh fly Sarcophaga ruficornis L. (Sarcophagidae: Diptera). Parasitol. Res. 114: 2325-31.

Singh, A, Tiwari, SK, 2016: Role of Fenoxycarb, a juvenile hormone analogue, on the developmental stages of rice-moth, Corcyra cephalonica Staint. (Lepidoptera: Pyralidae). Int. J. Zool. Invest. 2, 2:267-80.

Slama, K, Lukas, J, 2013: Role of juvenile hormone in the hypermetabolic production of water revealed by the $\mathrm{O}_{2}$ consumption and thermovision images of larvae of insects fed a diet of dry food. Eur. J. Entomol. 110, 2:221-30.

Smagghe, G, Degheele, D, 1994: The significance of pharmacokinetics and metabolism to the biological activity of RH-5992 (tebufenozide) in Spodoptera exempta, Spodoptera exigua and Leptinotarsa decemlineata. Pest. Biochem. Physiol. 49:224-34.

Taleh, M, Pourabad, RF, Geranmaye, J, Ebadollahi, A, 2015: Toxicity of Hexaflumuron as an insect growth regulator (IGR) against Helicoverpa armigera Hubner (Lepidoptera: Noctuidae). J. Entomol. Zool. Stud. 3, 2:274-7.

Tanani, M, Hamadah, Kh, Ghoneim, K, Basiouny, A., Waheeb, H, 2015: Toxicity and bioefficacy of Cyromazine on growth and development of the Cotton leafworm Spodoptera littoralis (Lepidoptera: Noctuidae). Int. J. Res. Stud. Zool. 1, 3:1-15.
Tateishi, K, Kiuchi, M, Takeda, S, 1993: New cuticle formation and moult inhibition by RH5849 in the common cutworm, Spodoptera litura (Lepidoptera: Noctuidae). App. Entomol. Zool. 28:177-84

Tripathi, P, Tiwari, SK, 2006: Potential of an insect growth regulator in the management of the rice moth Corcyra cephalonica Stainton, 1866 (Lepidoptera: Pyralidae). Polish J. Entomol. 83: 79-97.

Vinuela, E, Budia, F, Jams, J, Adan, A, Marco, V, et al, 1993: Differential larval age susceptibility of the medfly, Ceratitis capitata Wied. (Diptera, Tephritidae) to cyromazine. J. Appl. Entomol. 115:355-62.

Wang, QL, Liu, T-X, 2016: Effects of three insect growth regulators on Encarsia formosa (Hymenoptera: Aphelinidae), an endoparasitoid of Bemisia tabaci (Hemiptera: Aleyrodidae). J. Econ. Entomol. 109, 6:2290-7.

Weaver, JE, Begley, JW, 1982: Laboratory evaluation of BAY SIR 8514 against the house fly: effects on immature stages and adult sterility. J. Econ. Entomol. 75:657-61.

Wilson, TG, 2004: The molecular site of action of juvenile hormone and juvenile hormone insecticides during metamorphosis: how these compounds kill insects. J. Insect Physiol. 50, 2/3: 111-21.

Wright, JE, 1970: Hormones for control of livestock arthropods:L Development of an assay to select candidate compounds with juvenile hormone activity in the stable fly. J. Econ. Entomol. 63: 878-83.

Yokoyama, VY, Millar, GT, 1991: Potential of pyriproxyfen as a quarantine treatment for codling moth and oriental fruit moth (Lepidoptera: Tortricidae). J. Econ. Entomol. 84:942-7.

Zarate, N, Diaz, O, Martinez, AM, Figueroa, JI, Schneider, MI et al, 2011: Lethal and sublethal effects of Methoxyfenozide on the development, survival and reproduction of the fall armyworm, Spodoptera frugiperda (J.E. Smith) (Lepidoptera: Noctuidae). Neotrop. Entomol. 40, 1:129-37.

Zumpt, F, 1965: Myiasis in man and animals in the Old World: A Textbook for Physicians, Veterinarians and Zoologists. Butterworths, London. 